\title{
Social Death of Finitude in the Life of Institutionalized Elderly
}

\author{
Marta Eugenia Fontenele Pimenta* and Denise Cuoghi de Carvalho Veríssimo \\ State University of Campinas, Brazil \\ *Corresponding author: Marta Eugenia Fontenele Pimenta, State University of Campinas, Tessália Vieira de Camargo 126, Brazil
}

Submission: 眥January 25, 2018; Published: 些 February 02, 2018

\section{Opinion}

The concept of social death is defined by literature as the stage where the person is separated from social existence, when a person with social identity becomes a non-person. By this dimension, social death as a phenomenon is associated with diverse meanings and understandings, but in its centrality are the values of the social context, of culture and of its symbolic universes [1]. The understanding of finitude, in development theory, refers to processes of disengagement, autofocus and revision of life, concepts that are linked to reminiscences and the practice of uniting memory, subjectivity and the right to be aware of the last stage of life [2]. This communication addresses a reflection about how institutionalization of the elderly affects bio-psychosocially and how urgent is the design of innovative strategies regarding the right of the institutionalized elderly to receive care that respects their socio-cultural and spiritual identity, contemplating the right to a valid hearing on the existential content of finitude.

It is known that the parameters of age and gender in social death are discussed by British sociology [3]. In Brazil, the phenomenon of longevity and several socio-demographic factors contribute to the growth of the elderly population, which, as dependent elderly people, reside in the Long Stay Institutions (ILPIs). Considering that the death announced medically does not necessarily trigger social death, the point of interest turns to the protagonism of the context of residences for dependent elderly $[3,4]$.

The discussion of the finitude theme in old age has focused on the practice of living with dependent elderly people living in Long Stay Institutions (ILPI) and points out that the phenomenon of social death, when culturally installed, generates unfolding that affects the integrity of the subject and the ideal of a dignified aging, suggesting two unfolding negative repercussions: the anticipation of social death by the elderly residents and forgetting the memory of the other. Clinic managers and residences for the elderly bring in their cultural baggage the orientation that to the elderly the death theme is a funereal content, which should be avoided, regardless of the elderly person's desire to talk and listen attentively on the subject and also, disregarding its cultural repertoire and its spirituality.
Censorship to the subject of death imposes on those who are and will reach a single orientation: the word death, the verb dying is a taboo, something to be avoided at all times, whether during nursing tasks, bathing, breaks and in the possible moments of socialization between caregivers and the elderly. The institutionalized elderly [2] brings in their personal baggage the loss of significant persons in their lives, yet lives far from these references, without visual records, without remembrance, a kind of living from the perspective of erasing their identities in the social dimension and also of their affective patrimony. Being directed to forget or ignore the death of the companion is being tacitly directed to take as insignificant his own condition of subject, of social entity.

The first development: the anticipation of social death usually starts with the practice of managers and caregivers, who tacitly and with evasive approaches inhibit the initiatives of some elderly people to talk freely about finitude. How am I going to die? What would I like to do before I leave? How would I like to die? These and other possibilities of listening do not exist for institutionalized elders, many of them lucid and oriented about cultural, moral, and spiritual values about their identities as social subjects [1]. These practices transfer the experience of double censorship to the elderly- primarily because they are deterred and later because they implicitly collaborate to censor their peers, a kind of silent education about denial about death and how we can think about the last moments of life.

The second unfoldment: forgetfulness to the social memory of the other. These situations are when an elderly person needs medical care and is removed from the ILPI to receive specialized hospital treatment. The room is empty, but the presence of the friend removed without explanation causes anguish and apprehension in the other elderly [5]. He or she is no longer at the table for meals. The companion who shared the moments of sun in the garden does not appear anymore. Where will he be? The silence about the fate of the elderly resident who left for the hospital is interrupted rarely with a collective sigh. The lucid old people who remain in the nursing home know that the departed will not return will no longer be among them. 
The presence of death, in this unexplained, disguised form, is part of the silence imposed, of the non-right to the voice. Even if the old man who has left has not had his clinical death announced by the doctors, he must immediately die in everyone's memory. Then, the elderly, censored in their subjectivities on the theme finitude, begin to reproduce patterns of social death in their daily lives, and for many, the last physical and social context that determines the experience of living in this determining phase of their existence. In addition to the issues surrounding the right to a dignified aging, the debate on early social death and the inducement to forget the memory of the other refers to the concern with a necessary revision of the moral, cultural and ethical values that shape the concept of service to the dependent elderly [6].

This requires thinking about public policies and innovative initiatives that exclude the reproduction - intentional or otherwise - of social death in the dynamics that involve aging [3,4]. If Western culture does not value the voice of the elderly, which implies questioning in all areas that define life in society, the imposition of silence or censorship on existential contents that define rights and subjectivities is also a form of violence against the elderly. Psychologically based stressors have direct consequences on the physical and mental health of the elderly, reinforcing the premise [7] that psychological factors can increase a person's degree of disability beyond the expected projection of the physical illness or isolated injury. Studies that evaluate decision-making capacity in the elderly offer positive data about the capacity of elderly, institutionalized or not, to make decisions and the theme of death appears with the highest scores along with the results that reveal the domain in social relations [8]. Some aspects such as depressiondiagnosed as a more common symptom in elderly people living in ILPI than in the elderly living in communities - should be seen as priorities for a more complete diagnosis that generates more humanized strategies of the team of managers and caregivers. The imposing effects of a culture of denial of finitude narratives fall directly on the right of decent care to the dependent elderly in palliative care practices [1] and call the responsibility of society and government to an effective multidisciplinary vision for the performance of homes for the elderly.
New paradigms regarding the preservation of the social identity of the institutionalized elderly may have support in the conduct of the multidisciplinary team [8], in order to take into account reception procedures with stages ranging from pre-admission, to the beginning of socializing and the creation of innovative strategies aiming at a better adaptation in which the autonomy and the quality of life in the biological, psychological and social aspects of the elderly are promoted $[9,10]$.

\section{References}

1. Sweeting HN, Gilhooly ML (1992) Doctor, am I dead? A review of social death in modern societies. Omega 24(4): 251-269.

2. Cataldo JK (1994) Hardiness and death attitudes: Predictors of depression in the institutionalized elderly. Arch Psychiatr Nurs 8(5): 326-332.

3. Powers BA (1992) The roles staff play in the social networks of elderly institutionalized people. Soc Sci Med 34(12): 1335-1343.

4. Ramos LJ, Pizzato AC, Ettrich BDG, Melnik CS, Goldim JR, et al (2012) Aspectos éticos e nutricionais em uma amostra de idosos institucionalizados e não-institucionalizados. Revista HCPA. Porto Alegre 32(2): 223-226.

5. Marshall VW (1975) Age and awareness of finitude in developmental gerontology. OMEGA-Journal of Death and Dying 6(2): 113-129.

6. Mulkay M, Ernst J (1991) The changing profile of social death. European Journal of Sociology/Archives Européennes de Sociologie 32(1):172196

7. Christophe M, Camarano AA (2010) Cuidados de longa duração para a população idosa: um novo risco social a ser assumido. Rio de Janeiro, Ipea, Brazil, pp. 145-162.

8. Engel JH, Siewerdt F, Jackson R, Akobundu U, Wait C, et al. (2011) Hardiness, depression, and emotional well-being and their association with appetite in older adults. J Am Geriatr Soc 59(3): 482-487.

9. Camarano AA, Scharfstein EA (2010) Cap 6- Instituições de longa permanência para idosos: abrigo ou retiro? In: Cuidados de longa duração para a população idosa: um novo risco social a ser assumido. Rio de Janeiro, Ipea, Brazil, pp. 163-186.

10. Burlá C, Py L, Scharfstein EA (2010) Cap 10- Como estão sendo cuidados os idosos no final da vida? In: Cuidados de longa duração para a população idosa: um novo risco social a ser assumido. Rio de Janeiro, Ipea, Brazil, pp. 279-302. 